technology within its own organization. Sympathetic consideration has been given to the difficulties experienced in getting technical training by staff at such places as Dounreay and Calder Hall, but Mr. Birch was unable to say anything more in reply to Mr. Neave's suggestion for a large central institution for nuclear physics or nuclear technology. The Minister thought that any real danger of widespread redundancy is remote whatever the future of nuclear weapons; the Authority would be only too glad to utilize any skilled personnel released from the weapons group. Mr. Birch could say nothing definite about the future pattern of the Authority. It is a pioneering organization, he said, which must keep abreast of advances in scientific thought and of new knowledge. Both scientific and administrative skill are needed, and the Authority will continue to require to recruit good men for its expanding field. Mr. $\mathrm{H}$. Usborne suggested that the Authority is recruiting an excessive proportion of young engineers.

\section{International Control of Nuclear Weapons}

REPLYING to questions in the House of Commons on December 19, the Minister of State for Foreign Affairs, Mr. A. Nutting, said that no specific action has yet been taken on the proposal he made in the United Nations Disarmament Sub-Committee on October 7 for a conference of scientists representing each member country of the Sub-Committee to report on the possibilities of controlling nuclear weapons. A variant of this proposal was contained in a resolution passed by the United Nations Assembly the previous week, but was opposed by the U.S.S.R. Nevertheless, said Mr. Nutting, the Government is still seeking to get agreement to some scheme of this kind and has not abandoned hope of a disarmament agreement on conventional weapons, although it also hopes ultimately to achieve a comprehonsive agreement embracing nuclear weapons when means of control have been discovered.

\section{Journal of Analytical Psychology}

Axthough the followers of Freud have been well supplied with literature, the disciples of Jung have not been so fortunate. It is therefore gratifying to find that the Society of Analytical Psychology, London, has decided to produce its own journal, called the Journal of Analytical Psychology (1, No. 1 (1955). published by the Tavistock Publications, Ltd., 2 Beaumont Street, W.1; 12s. 6d. per issue or $21 s$. per vol. of two issues). In this first issue it is stated that "the decision to launch a Journal of the Society did not spring only from the publicly expressed observation that we produce no journal, but also, indeed one could say mainly, from the internal vitality of its members, now over forty in number". In the past the writings of the Jungian school have tended towards theorization rather than a clinical approach, and it is a good thing that most of the papers here are concerned with patients rather than myths. Nevertheless, since mythology and anthropology play such a large part in the Jungian approach, a great deal of space is devoted to the relationship of dreams to primitive thought. The most important paper in this issue is that of J. Layard, on boarsacrifice, in which the dream of a patient about cooking ham and being chased by a pig is related to the ritual sacrifice of pigs in Malekula. Another long paper is by Robert F. Hobson, on archetypal themes in depression, and Robert Moody writes on the function of counter transference. L. Stein writes on loathsome women, and Amy Allenby on the father archetype in feminine psychology. Anthony Storr contributes a note on cybernetics and analytical psychology. There is also a long critical notice on the collected works of C. G. Jung and on Jung's "Answer to Job". It is difficult for anyone who has not been educated in the Jungian discipline to evaluate these papers. Those used to analysing dreams by free association, using the patient's interpretation, are likely to feel that they might have been interpreted otherwise, but in any event such clinical work is always of interest. It is to be hoped that this journal prospers, if only for the fact that it allows one to see how others are thinking.

\section{University of Sheffield}

THE following have been appointed to lectureships in the University of Sheffield: Miss S. K. R. Clarke (bacteriology and virus diseases) and R. G. Siddall (fuel technology and chemical engineering). The present chair of fuel technology and chemical engineering in the University is to be called the Newton Drew chair in memory of the late Mr. and Mrs. W. Newton Drew. Mr. Newton Drew served on the University Council (1924-34), and was also treasurer of the University (1926-32) and a prochancellor (1932-34); Mrs. Newton Drew served on committees of the University for many years, and both were generous donors to the University. The present occupant of the chair is Prof. M. W. Thring.

\section{Announcements}

The Charles Mayer Prize of the Société de Chimie Biologique has been awarded for 1955 to Prøf. S. Ochoa (University of Chicago) and Mme. M. Grunberg-Manago (of the Centre National de la Recherche Scientifique, France). The Prize, which is worth 500,000 francs, has only recently been created and is to be awarded annually, provisionally until 1960, for distinguished work on nucleoproteins.

Mr. G. F. Adpams, scientific adviser to A. Gallenkamp and Co., Ltd., and Mr. H. B. Toft, formerly principal of Bath Technical College and recently a sales executive of the Company, have been elected to the board of directors of A. Gallenkamp and Co., Ltd.

The Royal Agricultural Society of England is offering its annual Research Medal, together with an award of a hundred guineas, for work of outstanding merit carried out in the United-Kingdom which has proved, or is likely to prove, of benefit to agriculture. Recommendations for the award can only be made by the head of the university department or research organization concerned. Such recommendations, with nine copies of the candidate's relevant papers, should be sent before January 31 to the Secretary of the Society at 16 Bedford Square, London, W.C.1.

The Education Panel of the Corrosion Group of the Society of Chemical Industry has established a prize of 25 guineas, to be awarded annually, for an essay or paper on any aspect (not necessarily research) of the corrosion of metals and its prevention. Competitors must not be more than twenty-seven years old, and their contributions, which may contain diagrams and photographs, should be about three thousand words in length. Entries must be submitted before March 31 to the Corrosion Group Essay Competition, c/o Society of Chemical Industry, 56 Victoria Street, London, S.W.1. 